\title{
Marx's Religious Dilemma: An Islamic Reply
}

\author{
Muhammad Rizwan Junaid1, Khadija Naz ${ }^{2}$ \\ ${ }^{1}$ Pakistan Institute of Management, Lahore, Pakistan \\ ${ }^{2}$ Department of Philosophy, Lahore College for Women University, Lahore, Pakistan \\ Email:dgmpim@gmail.com
}

How to cite this paper: Junaid, M.R. and Naz, K. (2018) Marx's Religious Dilemma: An Islamic Reply. Open Access Library Journal, 5: e4448. https://doi.org/10.4236/oalib.1104448

Received: February 26, 2018

Accepted: April 26, 2018

Published: April 29, 2018

Copyright (C) 2018 by authors and Open Access Library Inc.

This work is licensed under the Creative Commons Attribution International License (CC BY 4.0).

http://creativecommons.org/licenses/by/4.0/

\begin{abstract}
Religious concepts of Karl Marx were reactionary and he considered religion as a tool in the hands of oppressors and further captions it as an essence of no individual and social value. His influence travelled with him and socialist philosophy took a new turn and started abolishing religious norms in order to build an all atheist culture. Marx linked religion with economy and financial prosperity and made it responsible for societal failure. This research initiative is based upon Marx's writings and his sole contribution in the very right perspective of how he took the notion of religion? and strives to establish true position of religion as social phenomenon. The researcher focused to establish the fact that Marx's criticism of religion was not the criticism of religion but the existing world where it is being implemented and practiced. This paper attempts to counter Marx's religious confusions in the light of Islamic fundamentals and further tries to prove that Islam in its own capacity counters all the observations posed by Marx while referencing the word "religion".
\end{abstract}

\section{Subject Areas}

Philosophy

\section{Keywords}

Religion, Society, Dogmas, Theology, Criticism

\section{Introduction}

In order to comprehend religious concepts and ideologies of Karl Marx, we need to look into his early childhood. He was a born Jewish but later his family (his father) accepted Christianity, the influential Lutheranism, the core Protestant ascendency in Germany and adopted German Forename [1]. Ethnically Jewish and converted Christian, Marx chose altogether a new path for himself and proclaimed atheism [2]. This conversion and trading religion for safety and bet- 
ter future impressed Marx a lot and for whole of his life, he seemed linking religion with materials and sought quantitative answers pertaining to religious beliefs as he used to quantify religion and was of the opinion that if not productive then there was no use of any religion and for him, the productivity is something quantifiable and material.

Marx strived to establish an argument of religion based upon structural functionalism (a consolidate frame work for building theory that perceives society as an intricate system whose fragments work jointly to stimulate cohesion and constancy) [3]. In this very regard, Marx linked social structure and social functions together to develop a macro level orientation of the society. He further considered that a society passes through its evolutionary phases is like other organisms and the role of every fragment in this evolution is significant [4]. He was of the candid opinion that religion had definite applied purposes in society and it did reduce the pain of immediate sufferings and provided an illusionary relief to the masses that seemed similar to the function of opium for injured and sick persons but it evenly reduced their strengths and energies that required to counter the oppressive and suppressive move by the capitalists quarters (classes) who controlled productive means in a society and ruled over the masses.

Marx used the notion of religion in a very common fashion and without referring any specific religious doctrine, he tagged religion as opium for people \{Religion is the opium of the people ... Die Religion ... ist das Opium des Volkes\} [5] which is unjust. His philosophy of religion is controversial and seems reactionary as he undertook religion as a toll in the hands of ruling class with the help of which they controlled masses and mold social infrastructure in their favor or according to their wish. It was this very dimension of religion presented by Marx that Soviet Union and China declared atheism as the core religious ideology [6]. We will comprehensively discuss the criticism posed by Marx on religion with reference to three core religions Christianity, Jewism and Islam.

\section{Comprehensive Critique of Marx's Religious Views}

Karl Marx attempted to analyze religion through scientific and objective lens and linked religion with economics and society. Marx did not analyze religion directly but he scrutinized religion in referencing society and general economic conditions. He scarcely touches religion in a well-defined and methodical manner [7]. He, in-turn, relates religion with material actualities and monetary inequality and it is the point where he seemed religion as a weapon in the hands of oppressors who use it on poor and deprived masses in order to create an illusion of tranquility and comfort which is a fake picture presented before underprivileged and exploited classes within a society. Karl Marx was the first person who instituted the concept of social economics and mentioned that economics is the fundamentals of everyday life. He associated daily lives, marriages, churches with economics and in the same fashion, framed religion as a social institution created by human and real world and captioned that religion reflected the reali- 
ties of real world created by dominating forces in a society to divert the attention of masses towards an illusionary world where they can find peace and happiness for them. He filtered religion through historical and economic lens [8].

Marx wrote in A Contribution to the Critique of Hegels Philosophy of Right (Marx, 1843) "The foundation of irreligious criticism is. Man makes religion, religion does not make man. Religion is, indeed, the self-consciousness and self-esteem of man who has either not yet won through to himself, or has already lost himself again. But man is no abstract being squatting outside the world. Man is the world of man-state, society. This state and this society produce religion, which is an inverted consciousness of the world, because they are an inverted world. Religion is the general theory of this world, its encyclopedic compendium, its logic in popular form, its spiritual point d honneur, its enthusiasm, its moral sanction, its solemn complement, and its universal basis of consolation and justification. It is the fantastic realization of the human essence since the human essence has not acquired any true reality. The struggle against religion is, therefore, indirectly the struggle against that world whose spiritual aroma is religion. Religious suffering is, at one and the same time, the expression of real suffering and a protest against real suffering. Religion is the sigh of the oppressed creature, the heart of a heartless world, and the soul of soulless conditions. It is the opium of the people. The abolition of religion as the illusory happiness of the people is the demand for their real happiness. To call on them to give up their illusions about their condition is to call on them to give up a condition that requires illusions. The criticism of religion is, therefore, in embryo, the criticism of that vale of tears of which religion is the halo." [9].

Marx reactionary attitude towards religion does not contain any focused substance and he explained in the above passage that society and state produce religion; what is the rational basis of this statement. The sociology of religion clarifies that not society or state but religion frames societies and religious norms give comprehensive shape to social norms. Émile Durkheim, a famous Jew sociologist manifested that religion had been a source of friendship and solidarity [10]; he further mentioned, " $A$ religion is a unified system of beliefs and practices relative to sacred things, i.e., things set apart and forbidden-beliefs and practices which unite in one single moral community called a Church, all those who adhere to them." [11]. He stated religion was the most essential societal establishment of humanity, and one that escalated to numerous social customs. Christianity is even very clear about norms and fundamentals of a society; Bible captions "Now the works of the flesh are evident. sexual immorality, impurity, sensuality, idolatry, sorcery, enmity, strife, jealousy, fits of anger, rivalries, dissensions, divisions, envy, drunkenness, orgies, and things like these. I warn you, as I warned you before, that those who do such things will not inherit the kingdom of G-d." [12]. This verse manifests primary foundations of any society, it provides basic norms that frame the core infrastructure of any civilized society. In another verse, Bible verifies who will control the reins of society as, "or do 
you not know that the unrighteous will not inherit the kingdom of $G-d$ ? Do not be deceived: neither the sexually immoral, nor idolaters, nor adulterers, nor men who practice homosexuality." [13]. These verses vitally clear that religion provides elementary norms that shape a society and offer a well-knitted network with the help of which a societal infrastructure is to be governed and administered.

Islam is the religion that offers a very comprehensive, cohesive and organized fundamental to form and frame a society. Islam is a religion that encircles human in purely a natural manner and in this very context, Islam believes that human is social by nature and without any compulsion, man chose to be in homogenized setup with other humans. Quran in one of its verses captions, " $O$ mankind! We have created you male and female, and have made you nations and tribes, that you may know one another [not that on account of this you may boast of being superior to others]. Certainly, the noblest of you, in the sight of Allah, is the most G-[d-fearing among you" [14]. The captioned verse of Quran clarifies that existence of man in groups is in very nature of man as bestowed by his creature (The G-D). In align with this, when man forms societies and common living order then Quran lists the responsibilities a man owes towards society in which he lives, Quran says in one of its verses, "Surely Allah commands justice and the doing of good (to others), and giving to the kindred, and He forbids indecency and evil and rebellion. He admonishes you that you may be mindful. And fulfill the covenant of Allah, when you have made a covenant, and break not your oaths after confirming them; and you have indeed made Allah your surety. Surely Allah knows what you do." [15].

The Qur'an furthermore prohibits Muslims against committing obscenity, foul and revolt as well as those detrimental conducts that root the cessation of advancement in society, desolation to manhood and the downfall of nations. The Holy Qur'an also commands Muslims to accomplish their promises and prevents them from making promises without having them fulfilled. Muslims must respect their conventions and undertakings when they transact with others. They should endeavor towards doing deeds that delight Allah and not once go against Islamic commandments.

Marx rebellious attitude towards religion appears in the same passage as, the struggle against religion is, therefore, indirectly the struggle against that world whose spiritual aroma is religion. It is strange that on one side Marx considers religion as a tool in the hands of oppressors with the help of which they rule masses and on the other hand he manifests religious world is a world of essence that does not have any relation with the existing world. Marx clearly used two different terms as "spirituality" and "religion" but the inter-relatedness developed by Marx while using these two terms interchangeably is confusing.

Romanticism gave room to the term "spiritual" and romanticists defined spirituality as "wellbeing of mind-body-spirit" [16]. The holistic combination of mind, body and spirit is intrinsically the balance in one's life that provides ample 
chances to a human to travel within, exploring inner self. The question arises here is what is to be sought after travelling deep into inner self? In a very simplest sense, it is a form of religious experience as described by William James, "feelings, acts and experiences of individual men in their solitude, so far as they apprehend themselves to stand in relation to whatever they may consider the divine." [17]. He further concluded that the relationship among these three is solely attributed to soul as every human keeps a soul that exists in a spiritual space and guides a person performs the behaviors as he does in the physical world [18]. It is religion which paves the way for being spiritual and it is next to impossible to consider spirituality apart from any organized religious framework.

Marx was strong proponent of historical materialism and established his theory of history on the productive capacity of a society and its social relations of production that determined and defined evolutionary development and organization of any social union through the times [19]. Marx made it clear that in order to survive generations after generations, people in a society must focus upon material production and they should build social relations based upon their productive capacity; he primarily used means of production and productive forces as key terms to strengthen his thesis [20]. He altogether rejected the contribution, influence and impression of inner self and concentrated upon productive means of life that encircle human's material needs and necessities. He installed social relationships and connection of different classes in a society purely on the basis of their material position in a societal infrastructure [21]. It is for sure that the argument of social evolution presented by Marx carries immense weight but the rejection of spiritual and religious aspects generates an intrinsic confusion in respective arguments since societies travel through the pages of history and they carry forward a very rich compendium of social values, relationships, customs, rituals and ceremonies that not only provide proof for social evolution but also offer a civilized framework for balanced living conditions.

Since that; Marx views religion as an illusion that prevents a human to accept cruel realities and confines him to live in a world of superfluous contention that is good for nothing, a kind of escape from what is going on around, that is why he did not go deeper in order to comprehend the true essence of religion. It is for sure that spiritual tranquility and peace is fundamentally an outcome of religious consciousness. People who are more religious and close to whichever religion they follow are more composed, contended and complete in all spheres of their lives and appear more beneficial for others in a society. The metaphysical strength an individual collect from being religiously spiritual is a way toward success and eternal peace and a weapon to fight against odds at difficult times. Bible indicates the same in a verse as, "This book of the law shall not depart from your mouth, but you shall meditate on it day and night, so that you may be careful to do according to all that is written in it, for then you will make your way prosperous, and then you will have success. The focal point of meditation 
(mind + body + spirit) is to think in isolation and gain immense strength to be an individual with balanced mind body combination. The more a person thinks the more closer he goes to his creator and collects a vehement incessant impulse to fight uncertainties. Bible in another verse exemplifies it as, "Consider the ravens, for they neither sow nor reap; they have no storeroom or barn, and yet G-d feeds them; how much more valuable you are than the birds! "And which of you by worrying can add a single hour to his life's span? "If then you cannot do even a very little thing, why do you worry about other matters? Consider the lilies, how they grow: they neither toil nor spin; but I tell you, not even Solomon in all his glory clothed himself like one of these." [22].

Likewise, Jewism even favors the power of wisdom that gains through meditation, cogitation, contemplation, conviction, yoga and other similar isolated combination relating mind and body. Jacob Louis mentions with reference to Kabbalah, "In the Kabbalistic conceptual scheme, "wisdom" corresponds to the sefirah of wisdom, otherwise known as the "Father" principle (Partsuf of Abba) and "prophecy" corresponds to the sefirah of understanding or the "Mother" principle (Parsuf of Ima). Wisdom and understanding are described in the Zohar as "two companions that never part". Thus, Kabbalah represents the union of wisdom and prophecy in the collective Jewish soul; whenever we study Kabbalah, the inner wisdom of the Torah, we reveal this union." [23].

Islam is the foremost proponent of solitary meditation and it gives higher rank to those who meditate, there are number of verses in Quran that shed light upon thinking, securing wisdom and getting closer to G-d by being beneficial for others; and enable them to support what is right and fight against evil.

They are steadfast, truthful, submitting, charitable, and meditators at dawn. [24]

They are the repenters, the worshipers, the praisers, the meditators, the bowing and prostrating, the advocators of righteousness and forbidders of evil, and the keepers of G-D's laws. Give good news to such believers. [25]

During the night, you shall meditate for extra credit, that your Lord may raise you to an honorable rank. And say, My Lord, admit me an honorable admittance, and let me depart an honorable departure, and grant me from You a powerful support. [26]

The worshipers of the Most Gracious are those who tread the earth gently, and when the ignorant speak to them, they only utter peace. In the privacy of the night, they meditate on their Lord, and fall prostrate. And they say, "Our Lord, spare us the agony of Hell; its retribution is horrendous. It is the worst abode; the worst destiny." [27]

And put your trust in the Almighty, Most Merciful. Who sees you when you meditate during the night. And your frequent prostrations. He is the Hearer, the Omniscient. [28]

Is it not better to be one of those who meditate in the night, prostrating and staying up, being aware of the Hereafter, and seeking the mercy of their Lord? 
Say, "Are those who know equal to those who do not know?" Only those who possess intelligence will take heed. [29]

... praise and glorify your Lord before sunrise, and before sunset. During the night you shall meditate on His name, and after prostrating. [30]

Above are the few verses from Holy Quran that clearly explain that those who work on inner self are the individuals with towering heights and prime positions. It is evident from the very brief review from all three organized and universal religions that spirituality with religious focus provides ample chances to a human to come up to the mark; it does not only bring peace and contention in one's life but also enables one to lead a beneficial and balanced life in a society. Marx views religion through a materialistic lens as he perceived the same with religion when his father converted to Christianity for some material benefits. It was first encounter of little Marx with religion that left lasting impact on the mind of an innocent child and from there on he took religion as a socio-economic phenomenon and without developing deep insight into religious scripture, he came up with his reactionary remarks against religion.

The selected passage contains most famous quotation of Marx referencing religion as, it is the opium of the people. The abolition of religion as the illusory happiness of the people is the demand for their real happiness. If we talk with reference to symbolic logic then the captioned argument stands invalid as nothing can be deduced out of it. The major focus of this statement is "reactionary constructionism" that entails individual experiences as the prime source to build an argument. As we explained earlier that from the very childhood Marx came across religion as something that could tag and mold one's life in a different dimension. He took religion as a societal institution that seemed dependent upon physical and economic certainties for its existence and carried no sovereign recognition of its own and primarily generated by productive forces and factors in a society for their immediate interest to control the masses by keeping them in an illusionary world full of pleasures and all free from pain.

Marx encircles history and economy as two core subjects to study religion and he assumed economics played key role in historical progression while religion as dominant destructive factor that not only hampered social advancement but even claimed lives of millions of innocent humans in blood stained wars. Marx has not had established any argument proving religion as a destructive force rather issued plain statements and if it is the case then there is no choice for us except we better go with Marx or reject Marx; but it seems difficult perhaps even improbable to establish an argument as Marx did not initiate one. Why he took religion as a destructive or cruel source; since his early childhood, Young Marx developed intrinsic hatred towards religion and announced himself as atheist and remained same for whole of his life.

In this very context, it is to be seen that Marx joined the club of young Philosophers who called themselves Hegelians. Hegel was an idealist and he believed that process of thinking (subjective) is based upon real world (objective) as this 
relationship provides an identity and recognition to human thoughts [31]. Hegel captioned that all ideas are merely expressions of factual necessities [32]. This basic idea presented by Hegel that material forces are essential to the real world not the ideas and concepts is the rudimentary foundation Marx used to base all of his ideas [33]. In the perspective of above, Marx established his philosophy on two core foundations that human behaviors are controlled by existing economic certainties and entire human history is nothing but struggle between classes, the one who possessed all the resources and the ones who were deprived of these resources necessary for survival and he further exemplified that all human institutions including religion were developed on the same basis [34].

Marx came across two core problems in his religious understandings as 1) he rolled between Christianity and Jewish faiths and failed to connect himself with any one of these and eventually declared himself an atheist, 2) he did not study religion as a separate subject and without jumping deeper into religious scriptures, teachings, norms and concepts, he tagged religion as a tool in the hands of oppressors. He tried to understand religion through a reflective index with reference to the purpose served by a religion in a society rather than studying and comprehending religious beliefs first in isolation. He materialized religion in a sense that it should serve any material purpose in a society.

Marx compared religion with capitalism and established his argument in a manner that as capitalism deprived us from our labor and its value and developed a state of alienation in us; same as religion took away our ambitions and highest models, ideals and leaders and inclined us towards an unidentified and anonymous being named G-D [35]. Marx rests his argument on "Philosophical materialism" that diminishes all possibilities of any metaphysical, super natural and omnipotent being (G-D). It appears a clear and well defined detachment between religion and society as Marx did not consider religion adding any physical value in our society and It is all vague as how did he come down to this conclusion.

Religion is the immediate and primary source that links physical and ideal world; it further makes sure that pleasures and happiness of the world hereafter simply depends upon the deeds he performs in this world. Every religion provides comprehensive code of life that guides and helps it followers to act accordingly. It is not an illusion that religion provides happiness and gives way to forget the atrocities and cruelness of this world but it also relates both the lives in an understandable and plausible fashion and makes it vitally vivid that if people are not performing their role as they are supposed to then they will be punished in life hereafter and the people who are suffering in the hands of oppressors will be fairly rewarded. Bible mentions in one of its verses as; not everyone who says to me, "Lord, Lord," will enter the kingdom of heaven, but the one who does the will of my Father who is in heaven. On that day many will say to me, "Lord, Lord, did we not prophesy in your name, and cast out demons in your name, and do many mighty works in your name?" And then will I declare to them, "I never knew you; depart from me, you workers of lawlessness. [36]; further the Bible sets a straight path to pass life in this world with reference to dos and 
don'ts as; Now the works of the flesh are evident. sexual immorality, impurity, sensuality, idolatry, sorcery, enmity, strife, jealousy, fits of anger, rivalries, dissensions, divisions, envy, drunkenness, orgies, and things like these. I warn you, as I warned you before, that those who do such things will not inherit the kingdom of G-d. But the fruit of the Spirit is love, joy, peace, patience, kindness, goodness, faithfulness, gentleness, self-control; against such things there is no law. ... [37]. These verses clearly show that Christianity links this life with after life; the feelings and emotions developed by humans are not illusions.

Jewism is very clear about this connection between this world and the world hereafter; Torah defines in one of its verses as; The world "stands"-in such a way that it is supported solidly-on three things. Through Torah, divine service, and acts of kindness $G$-dliness will be revealed here in this world to the same extent that it is revealed in the highest world, the world of Atzilut. [38]. This verse evidently indicates how a man should pass his life in this world in order to win the highest point. In another verse, Torah sets the guiding path for his followers, as if they follow the righteous path then they will find eternal peace and pleasure in after life. It captions, And remember that you were a slave in the land of Egypt. And Yahweh brought you out from there with a strong hand and an arm stretched out. That is why Yahweh commanded you to keep the Sabbath day. Honor your father and your mother, as Yahweh your god commanded you, so that your days may be long, and so that it will go well for you in the land which Yahweh your god is going to give you. You shall not murder, you shall not commit adultery, and you shall not steal. And you shall not testify falsely against your neighbor. You shall not desire your neighbor's wife, and you shall covet your neighbor's house, his field, and his male or female slave, his ox, or his donkey, or anything belonging to your neighbor. [39]

Islam vitally explains the connection between both the worlds and elucidates that every follower must follow the code of conduct in order be high in the eyes of creator. Quran mentions in one of its verses as; "It is not righteousness that ye turn your faces Towards east or West, but it is righteousness-to believe in Allah and the Last Day, and the Angels, and the Book, and the Messengers, to spend of your substance, out of love for Him, for your kin, for orphans, for the needy, for the wayfarer, for those who ask, and for the ransom of slaves, to be steadfast in prayer, and practice regular charity, to fulfil the contracts which ye have made, and to be firm and patient, in pain (or suffering) and adversity, and throughout all periods of panic. Such are the people of truth, the Allah-fearing." [40]. In another verse Quran says, "Whoever brings a good deed (Islamic Monotheism and deeds of obedience to Allah and His Messenger ${ }^{S A W}$ ) shall have ten times the like thereof to his credit, and whoever brings an evil deed (polytheism, disbelief, hypocrisy, and deeds of disobedience to Allah and His Messenger ${ }^{S A W}$ ) shall have only the recompense of the like thereof, and they will not be wronged." [41]. Both of these verses vitalize that our deeds and actions pave the way towards salvation and happiness. It is not illusionary but a matter of belief. 
Marx thinks that people, who are religious, live in a fantasy world and they are being fooled by others who deprive them of livelihood but he did not give any rational or epistemological argument to prove his point. Religious foundations are very strong and stable and they are framed on G-dly scriptures; it is not the case that these are documented by humans and can be altered for any good or bad purpose. G-d choose selected humans to represent HIM in this world and guide masses towards right path. When one calls religion as opium then it is simply a sick reaction of a depressed soul that does not carry any weight or value. It can be a popular argument being quoted by millions but it cannot be a logical argument.

Marx used the word "religion" in a very loose and generalized manner and he encompassed all the religions into it as a whole which is not promising and in addition to it; he did not exemplify any core religion to support his statement. We cannot undertake religion in a common denotative sense as religion cannot be generalized like other social phenomena and it carries a very compact and comprehensive meaning of its own. If one talks of Christianity then one should go through the Biblical interpretations in order to support one's statements regarding Christianity and these interpretations will be all the way different from interpretation of Holy Quran as Quran discusses things in altogether a different fashion. The religious variations in Marx's life made him a person without any religious identity so was the case with many people during that times.

\section{Reactionary Materialism}

Materialism holds that matter is the fundamental substance in nature and all essences as psychological traits and cognizance is outcome of material interfaces [42]. There is a very strong relationship between materialism and physicalism that holds the view that existence in its holistic sense is ultimately physical. Philosophers divided in two categories: idealism and materialism while contrasting one another. Idealists maintained their stand that ideas are primary and matter is secondary; on the other hand materialists manifested that matter is primary and ideas are secondary as they rely upon material realities [43].

In the beginning of $19^{\text {th }}$ century Karl Marx and Fredrick Engels established materialistic concept of historical progression and drew their thesis on contribution of human labor and social institutions that donated well towards re-shaping the world in its prevailing condition; Marx considered religion even as a social institution inspired by material realities and he further argued that if religion did not shoulder its societal responsibilities then there was no use of religion [44]. If we look into the foundations upon which Marx rested his thesis then it was simply reactionary materialism.

Marx did not use the core approach of the school of thought he belonged but he took altogether a novel turn and labeled religion as a tool in the hands of ruling class (Bourgeois) against labor class (Proletariat). He established three core objections against religion as [45]:

1) Religion does not serve any material purpose for the betterment of society. 
2) Ruling elites use religion as a tool to control masses and oppress them.

3) Poor people with sound religious beliefs fool themselves by thinking of a world free of all atrocities and hardships.

All above objections carry an intrinsic intensity that Marx brought forward from his childhood and remain with him for whole of his life. His approach and attitude towards religion has always been reactive and retaliated; he considered religion as a productive social institution and "was not ready to think the focused role of religion in the life of human beings. His arguments are more personal than based upon any logical discourse. Since that, there is no concept of after life in Marx's philosophy that is why he insists on humans to fight for better life on earth instead of looking for heavens. Marx believed that religion gave way to oppress people to remain contended against the miseries of life as they would be rewarded in an unseen world for their sufferings. It is his interpretation of religion that cannot be applied to all the religions so forth.

He witnessed the social disparity and oppression of people in the hands of powerful minority and then he saw that these people found solace and consolation in religious gatherings, so he summarized religion as opium that leaves people oblivious of their tiring circumstances but by passing time conditions go worse. It is purely a personal opinion that does not contain any philosophical underpinnings. He focused upon Christianity, Jewish religion, Babylonian religion, Greek mythologies etc. and he came across contradictions and he was very right in building these controversies but why did he not search for real answers to his religious questions? He used the word "religion" and posited that all the religions are mere bunch of false promises and in this material world there is no place for any religion or an omnipotent G-d.

\section{Core Issues in Karl Marx's Analysis of Religion}

Marx viewed religion in the outlook of history and economics; he further considered religion as a social institution that meant to act as other social institutions. He established his argument purely on his personal understanding through a condensed lens. The reactionary approach of Marx was significant in every philosophical initiative he took, and the core reason was the social and personal surroundings in which he remained for whole of his life but his approach towards religion was primarily biased and centered. We encircle core deficiencies found in Marx's analysis of religion.

\subsection{Conceptual Generalization}

Marx came across one core religion in his life that was Christianity and he quoted word religion keeping in view Christian doctrines but referencing two specific areas as $G$ - $d$ and after life, he enveloped all religions and it is for sure that in a radical context these concepts cannot be applied to all religions in general. It seems that Marx was highly inspired by Hegel and since that, Hegel considered Christianity as the highest form of religion so he undertook the notion that whatever encircled by Christianity is equally applicable to all other religions. 
If we go further keeping this argument, then it is mere assumption that does not carry any logical rationale to prove the point. It carries a myopic vision that findings of Christianity being applied to all other religions without studying or referencing other religions. Marx took further the assumption of Hegel along with his personal baggage that was with him since the very childhood.

\subsection{Social Institutions and Religion}

Marx analyzed religion through historical and economics lens and he was of the firm opinion that religion is like other social institutions and it is an outcome of dominant social systems. This argument is even weaker in the very context of history and all the ancient and prevailing civilizations of the world. Religion provides form and frame to establish and develop any social infrastructure; ancient Greek theology was polytheistic and they believed in number of G-ds and goddesses who provided rules and regulations to install a commune and social structure [46]. [47] mentioned that Christianity was the largest religion in Europe that influenced art, culture, philosophy and law and till date this influence can vitally be witnessed. It would be a very detailed discussion, in order to save time we direct our discussion towards contemporary times. If we take Marx's argument then there is no proof to support this argument. Take the example of Protestantism which is a dominant Christian sect in many parts of the western world; if Marx is right then Capitalism should come prior to Protestantism but we do not exactly find the same. These are historical evidences in the light of which Marx is not true and his assumption cannot be taken as it is.

\subsection{Economic Focus}

Marx formed his fundamental argument of religion on economics; since Marx used economics lens to study all aspects of society and in terms of having this focus he seemed biased towards all of his philosophical attempts. He was of the opinion that only human can provide value based production. It means that if human laborer are used in a manual production system then they would produce more surplus value (return on investment) but in reality, the case is altogether otherwise as machine oriented or technologically automate system produce more surplus value than human dominated productive system.

If we take further the same argument then according to Marx value is based upon human labor [48]. If a worker works upon a piece of wood and produce an ugly sculpture then the value of the sculpture would be less than the value of the piece of wood as the laborer was supposed to come out of a beautiful sculpture. The value of any produced object is not based upon the worker labor but the purchaser, if a purchaser is willing to pay for this ugly sculpture then it is the choice of the buyer not the producer.

\subsection{Summarizing Marx's Religious Views}

In the light of above discussion it is evident that Marx religious dogmas had two basic deficiencies as 1) These were based upon Marx personal perspective without 
any concrete logical or historical interpretations and 2) These were argued keeping Christianity under view and he generalized Christian teachings as hall mark representing all religions round the globe. The philosophical elucidations of Marx's religious stance lack the core body of knowledge and it replicates intense reaction of Marx purely in a personalized fashion. It is clarified here that Marx drew its focus upon how religion was being practiced in his times. It means that when Marx registered his arguments against the atrocities of dominant class and captioned religion as a tool in their hands then primarily, he is referencing the wrongdoings and manipulations of oppressors and it has nothing to do with the core teachings of a religion.

We need to elaborate here that all messengers were chosen people and they were sent to keep humans on the guided and right track; they acted straight under G-d's command. Furthermore, they never talk on their own rather express whatever is directed by the omnipotent creator whom they represent before humanity. From Hazarat Adam ${ }^{\text {as }}$ till Hazrat Muhammad ${ }^{\text {pbuh }}$ there were around 124,000 personalities served the Prophethood. Islam was the last religion in this chain as Hazarat Muhammad ${ }^{\text {pbuh }}$ was the last prophet in this chain. Marx did not have any knowledge of Islam and its body of Knowledge. It is so strange that without acquiring any knowledge of most contemporary religion, he cited religion as opium. He tried to prove that religion is totally disconnected with other social institutions and it is being used as a weapon in the hands of dominant minority to control poor masses.

Our aim in the upcoming section is to counter this confusion of Marx through Quranic verses (the last book revealed upon Holy Prophet Muhammad ${ }^{\text {pbuh }}$ ) and biblical interpretations. It is evident that G-d sent number of His dear messengers who spread His message across the globe. Since the very beginning till the last Prophet, every messenger passed through evolutionary phases enveloping human history. In this context, Islam is the final heavenly religion that encircle all aspects of human life and provides complete code of life, It is difficult perhaps even implausible to quote all the verses but we would keep our discussion close to the core thesis of this paper in order to counter Marx arguments in the real context.

\section{How Does Islam Counter Marx's Religious Confusions?}

In this section, we focus our discussion across Islamic doctrine and further look into the facts if Islam has any say regarding bringing betterment in this life and provisions of any specific code to pass their lives. We keep our discussion around the sociological view of Islam in terms to exemplify Marx's understandings of religion in the real context of words. Our prime intention in this research initiative is to encircle only those areas that clarify a close link/relation between human beings and social setup in which they live and pass their lives.

\subsection{Good Governance}

There is very heavy responsibility, as prescribed by Quran, towards those who 
are being governed and every government is bound to follow specific rules and regulations that have been derived for the larger interest of all human beings irrespective of their religion, caste, ethnic origin, language or class. Quran mentions:

"Those when given authority in land, establish (system of) salah, give zakah and enjoin what is good (mauruf) and forbid what is wrong (munkar)" [49]. It further captions, " $O$ you who believe stand up as a witness for Allah in all fairness, and do not let the hatred of people deviate you from justice ('adl). Be just, this is closest to piety" [50]. It verifies that Islam concept of good governance is not materialistic or mechanical but purely qualitative in nature. The governance system of Islam is based upon seven fundamental principles:

1) Rules of Law (As-Shura)

2) Khilafah

3) Accountability

4) Transparency

5) Justice

6) Equity

7) Al-amrbilmarufwanahi an al-munkar (calling people towards good deeds and refrain them from being involved in bad deeds) [51].

Islam strongly criticizes any aristocratic or capitalistic form of governance but clearly states that shura (consultation is the most significant principle of Islamic jurisprudence, there is a complete chapter in Holy Quran named al-shura that further signifies the importance of seeking advice of those who are poised, noble, gentle and prominent in society for their good reputation). Quran states, "Those who hearken to their Lord, and establish regular Prayer, who (conduct) their affairs by mutual consultation among themselves, who spend out of what We bestow on them for Sustenance" [are praised]" [52]. Mohamed S. El-Awa detailed the criteria for selecting those who can represent whole society (ummah), "Thus, no ruler is to be chosen and put in power without the will of the Ummah. Nor shall the Ummah be deprived of this right under the pretence of preserving its unity, protecting its interests, reviving its glories or any similar claims. In this respect, the decree of "Umar b. al-Khattab was very clear when he advised that anyone who tried to force himself or someone else into a position of command without the consent of Muslims based on consultation with them must be punished like those who stir up dissention (fitnah) on earth, that is, 'you are free to kill him'." [53].

Islam expounds that it is solely be the prerogative of shura to select rulers and their strict criteria is to select the one as ruler, elite leader as Quran mentions "Owing to Mercy from G-d, you were gentle in dealing with them [your companions]. Were you harsh [and crude], hard of heart, they would have fled from you. Therefore, pardon their abuses, seek $[G-d s]$ forgiveness for them, and consult them in the affair. Once you have resolved on a course of action [be decisive] and trust in G-d. Surely, G-d loves those who trust in Him." [54]. This 
verse is a clear and vital example covering instructions for those who are in position to lead. In a hadith The Prophet mentioned, "All of you are shepherds, and each of you will be asked concerning his flock." [55]. Islam paves stringent guidelines for those who are in the driving seat.

Islam makes it clear that everyone in a dominant or leading position, with all luxuries and pleasures of life, is not privileged because of his wealth or power but because G-d is kind and merciful. In return, G-d wants them to repeat the same with fellow beings. The Holy Prophet ${ }^{\mathrm{pbuh}}$ made it clear, "No one humbles themselves for the sake of G-d except that G-d elevates him." [56]. It is vitally clear in Islam that every individual and follower is abided by the verdict of sharaih (Islamic law) and no one is above or exempted as Quran mentions in one of its verses: "It is not for a believing man or a believing woman, once Allah and His messenger have decided a thing, that they should have a choice about their decision; and whoever disobeys Allah and His Messenger, he has indeed strayed into open/plain error." [57]. Another verse shows the decisive order against those who does not follow the instructions and disobey them, as; "And let those who oppose the Messenger's commandment beware, lest some fitnah (affliction) befall them or a painful torment be inflicted on them." [58].

Above comprehensive discussion makes it clear that Islam offers a complete and compact code to be followed by those who are powerful with wealth or position in a society and wealth and power always come with a strict sense of responsibility and accountability. The more wealth and position one enjoys in society, the more is one held accountable regarding use of wealth and authority, Islam links power and wealth with a sheer sense of answerability and the final verdict is the verdict of G-d.

\subsection{Islamic Economics and Society}

Islamic economy is the strongest argument that can be presented to counter Marx's religious thesis as Marx explained at various occasions that economic disparity is the root cause of all evils and Capitalism is the source of all evil effects on society [59]. Islam is the only religion that provides a complete and comprehensive system of distribution of wealth in order to maintain social balance. The most important aspect of any and every Islamic system is that these systems as presented by Islam, do not undertake and individual or collective influence and are under strict compliance laid down by shariah (Islamic law). Islamic jurisprudence has conventionally undertaken what is obligatory, forbidden, fortified, dejected, or permitted, [60]; in the light of Quran and the established practices of Sunnah. It encircles all socio-economic issues as money, property, employment, taxes etc.

Islamic economics is primarily based upon moral laws prescribed by Quran and Sunnah; these can be summarized as:

1) Behavioral models and ethical fundamentals in the light of Quran and Sunnah. 
2) Collection of zakat and relevant Islamic taxes.

3) Prohibition of Interest charged on loans [61]

Above three fundamentals advocate that Islamic economics is a mid-way between capitalism and socialism as Islamic economics does not carry the shortcomings of these two systems [62]. The prime focus of Islamic economy is to reduce the gap between rich and poor and this gap keeps on reducing as prosperity increases [60]. Islam provides a framework with the help of which the core objectives of Islamic financial system can be achieved and the concept of welfare economy be understood. Islam focuses upon fundamental parameters in order to establish its system of economy:

- Discourage the hoarding of capital [63]

- Expose lenders to risks through profit sharing and individual investments [64]

- Discourage the hoarding of food in order to avoid price swings [65]

- Impose taxes (zakat) on rich to ensure equal distribution of wealth [66]

- Control unlawful seizure of land [65]

MurtazaMutahhari made it clear that Islamic economy is a revolutionary ideology to change the corrupt reality into a pure one and "not a science of political economy" or "an objective analysis of existing reality" [67]. It openly distinguishes Islamic economic system from western financial system and further exemplifies that Islamic financial system is not an outcome of any intelligent financial effort but purely designed by G-d that covers economic affairs of an individual's life (micro perspective) and collectively as a nation (ummah) (macro perspective) [68].

The focused aim of any financial system is not to divide a social system but to produce a social cohesion and solidity that connects people to people and discourages the internal divide and initiate a compact social capsule based upon equality and balance of resources. Ibn-e-Khaldun in his famous History of the World related this social cohesion with division of labor and further illustrated that social growth and development stimulates the balance between supply and demand that not only provides employment to a large number of people but also paves the way towards flow of wealth among all classes in a society [69].

Baqar-al-Sadr expounded that Islam is a religion devoted to social justice, equal circulation of wealth and serving the cause of deprived classes; Islamic financial system is a strong contradiction towards capitalism and Marxism [70]. Free economy and social welfare is the keys of Islamic economy and what Marx mentioned about social disparity and posed religion into it is false; as he only encircled his understanding of religion without studying religion as a whole.

Islamic financial system does not consider any one as the owner of the wealth and Quran plainly states that only Allah is the owner of your wealth you are mere custodian of what you have; one of the Quranic verses captions, "And give them of the wealth of Allah which He has given you." [71]; at another place Quran indicates, "Believe in Allah and His Messenger, and spend whereof He has 
made you heirs" [72]. Islam announces severe punishment for those who hoard wealth and do not spend in the way of Allah, "And those who hoard up gold and silver and spend not in the way of Allah; announce to them a painful chastisement." [73]. Circulation of wealth is obligatory upon those who hoard wealth and Islam wants every person in a society to be the shareholder in Islamic economy; Islam gives the first social economic system that is meant to serve every individual on planet earth. Quran says, "Whatsoever Allah may restore unto His Messenger-is due unto Allah and unto His Messenger-the orphans and the needy ... so that it may not be confined to the rich amongst you." [74]. These principles mark that Islam differs undoubtedly, from man-made (capitalism, materialism, socialism) economic systems, in undertaking economic problems and link every economic problem with society and call it socio-economic problem.

Capitalism is an economic system or an ideology primarily based upon private ownership of means of production and their utilization for profit maximization [75]. Capitalism believe that resources are limited but wants are unlimited so we need to go for more production to parallel the requirement for consumption and for this reason Capitalists strive to encircle more and more people; it is the core reason that they always talk about GDP (gross domestic product). On the contrary, Islam focuses upon distribution of wealth not just production and it attempts to solve the problem of excess production in a radical manner. Islam considers every individual as an individual human being who keeps all the rights to satisfy his/her basic needs and it is possible not by producing more but by distribution of wealth among all. Once the basic needs are fulfilled then these individuals appear more powerful to produce more. Islam strongly resists to produce more for rich that leaves poor without any basic needs. Islam sturdily emphasizes upon fulfilling basic rights that is the right of every individual in a society.

\subsection{Islam and Fulfillment of Basic Needs}

The concept of fulfilment of basic necessities is as long-standing as Islam in its capacity as the final religion. It is imperative to understand "basic needs"; traditionally, the basic needs comprise of food, shelter and clothing [76]. International Labor Organization (ILO) has further exemplified this list by adding education, sanitation and health also as basic needs that are to be fulfilled and are the basic rights of every individual that should be covered by all national and international policies [77]. Ibrahim Mustafa defined basic needs as "Everything a person cannot do without, everything which is needed." [78]. Imam Shatibi further broadened the meaning of Basic needs as, "Necessities mean those things one cannot do without to fulfill his worldly and "deeni" (Islamic) needs. If he does not get them, he will not be able to live his life properly; rather his worldly affairs will run into difficulty to the extent that life, itself, may come to an end." [79]. Ali Hisbullah took the definition further, as "Necessary aims are those on 
which worldly and religious life is based on and if one loses them, his worldly life will get uprooted" [80]. Holy Quran seals the discussion in one of its verses as, "And in their wealth is the due share of the beggar and the destitute." [81].

The above verse of Holy Quran makes it clear that basic necessities of life is the right of every person and poor and deprived have their share in the wealth of rich. Rich are bound to pay zakat (Islamic tax) to the poor and needy and along with it; it is their collective responsibility to reach poor and look after their needs, provide them food, shelter and clothing. Failing to do so will make them stand before G-d and they will be made accountable for their negligence [82]. In continuation of this, a famous hadith from Al-Tirmidhi, Holy Prophet ${ }^{\mathrm{pbuh}}$ mentioned "The son of Adam ${ }^{4 . S .}$ has no rights except for four things i.e., a house in which to live; clothes by which to cover his "satar" (private parts); a piece of breadl roti and water." [83]. Noted Islamic scholars also emphasize in their writings about fulfillment of basic needs. Imam Ghazali clearly encircled that bread, water, home and clothes are the basic need and right of every individual irrespective of religion, caste, ethnic origin, nationality etc. and these needs should be fulfilled by the ones who control the means of production in a social setup [84]. He narrated the same as "Nourishment and food is to stay alive, clothes to shelter him from cold and heat, a house to live in and save him from heat and cold and to save him and his family from death due to lack of wealth." [85].

Al-Damishqi was of the candid opinion that needs of man are more than an animal and some of these needs are in-built and in-born as clothes to wear, food to eat, water to drink and a shelter to live in [86]. Al-Marghinani made it clear that food, clothing, a place to live in and drinking water is the right of every man and women that should be shouldered by the rulers and dominant class [87]. The second Caliph HazratUmar ${ }^{\text {ra }}$ made it mandatory for his governors to ensure the provision of following for every individual living under the control of Islamic state:

1) The necessities relating to food;

2) Clothes for the winter and summer seasons;

3) Conveyance for normal movements. [88]

There are numerous Islamic scholars who encircled these basic needs but in terms to save time, we confine our discussion to the above references. It is pertinent to mention here that Islam does not encircle fulfilment of these basic needs at grass root level but exemplifies an acceptable standard of living that is to be maintained by every individual in a society as personal integrity is very important in Islam and Islam emphasizes that individuality of every person should always be respected. The word "need" envelops some other necessities that are bunched with captioned basic needs; Shahab-al-din ramli, a renowned Muslim scholar narrated the same as "It is necessary to provide such clothes that cover the whole body and protect a person from heat and cold. Other things are also needed in addition to these, fees of a doctor, money for medicine, and a servant for the disabled." [89]. 
Islam does not end here and further takes the discussion regarding basic needs to a new level and captions that even marriage is also one of the basic needs and many notable Muslim scholars undertook marriage as a necessity. Holy Prophet ${ }^{\mathrm{pbuh}}$ also explained the same as, "Those who hold a position in government (as servant or a governor), has a right to be given the following from the bait-ulmaal, 1) Marriage arrangements, including the expenses of the wife and children; 2) If he does not have a servant, he should keep one; 3) If he does not have a home, he should arrange for one." [90]. This hadith clearly mentions that the government should shoulder the responsibility of every individual and failing to do so will make it accountable in front of the highest authority, the G-d.

\subsection{Islam and Corrupt Rulers}

Marx seemed very annoyed of those who deprived others from basic needs and use their power and position to expand corruption in society. Marx considered religion had nothing to do with it and those who corrupt a society keep their cover under the cloak of religion. Islam counters Marx's disagreement with very comprehensive and compact argument. Holy Quran mentions in one of its verses as "And $O$ my people! Give full measure and weight in justice and reduce not the things that are due to the people, and do not commit mischief in the land, causing corruption." [91]. Islam takes the discussion further and warn those who aid corrupt leaders, Holy Prophet ${ }^{\text {pbuh }}$ clearly describes the same as "Allah is with the Qadi as long as he is not tyrannical, but when he is, He departs from him and the Devil attaches himself to him." [92]. In addition to it, Islam does not allow any ruler or powerful in position to exercise corruption, if an Imam and amir goes corrupted then first he must be counsel keeping privacy but if he does not abide by the Quran and Sunnah then he should be publicly criticized and penalized or punished. Abu Hurairah ( $R A)$ narrated Rasulullah $(S A W)$ said: "The Israelis used to be ruled and guided by prophets. Whenever a prophet died, another would take over his place. There will be no prophet after me, but there will be Caliphs who will increase in number." The people asked: "O Allah's Apostle! What do you order us (to do)?" Rasulullah (SAW) said, "Obey the one who will be given the pledge of allegiance first. Fulfill their (i.e. the Caliphs) rights, for Allah will ask them about (any shortcoming) in ruling those Allah has put under their guardianship." [93]. Another Hadith announces the status of such a ruler as Ma' qil narrated "I heard Rasulullah ( $S A W$ ) saying. "Any man whom Allah has given the authority of ruling some people and he does not look after them in an honest manner, will never feel even the smell of Paradise." [94].

Islam never preaches to follow and obey the corrupt rulers but it strongly believes in fighting against them and confront them openly. Holy Prophet ${ }^{\mathrm{pbuh}}$ mentioned "Verily, among the greatest of struggles is a word of justice in front of a tyrant." [95]. Islam always motivate masses to keep a check on those who rule and govern them; it gives the followers a clear line of action and stimulate them 
to stand against corruption and fight it till the last end. Islam does not believe in Isolation and disconnection.

\subsection{Islam and Prevailing Financial Markets}

The Islamic economy advocates generating wealth but with full participation from all stakeholders; it offers investment and employment opportunities in a free trade economy to everyone. Islam emphasizes that real economy generates a sense of fulfillment, peace and satisfaction for all participants as everyone pays one's part and generates his share of wealth [96]. The autonomous wealth generating concept by a powerful and dominant cluster is strongly condemned in Islamic economy. The sense of ownership is very powerful in Islam and Islam strongly contradicts the current financial market where an ordinary shareholders has nothing to do with the company affairs and he sits outside and wait for the benefits (in case of profit) while Islamic concept of shareholding paves the way for direct ownership in the company rather than a share certificate in the form of a piece of paper [97].

Islam is the strongest opponent of interest (riba) and there is no concept of interest in Islamic economy. Financial capital can generate income but by bearing and sharing profit/loss equally. The loan providers as banks and DFIs play their role in fulfilling the ready financial requirement of the market but there will always be an element of risk [98]. In order to avoid loss, the loan provider and receiver play their roles towards better utilization of financial resources but the element of risk remains evident and undertaken in all such transactions. Holy Quran is very clear in handling the issue of interest (usury/riba) and strictly refrain all followers from indulging in this practice of receiving and giving interest on financial transactions. Quran mentions "Allah does not bless usury, and He causes charitable deeds to prosper, and Allah does not love any ungrateful sinner." [99]. In another verse Quran cautions followers in these words " $O$ you who believe! do not devour usury, making it double and redouble, and be careful of (your duty to) Allah, that you may be successful." [100]. In continuation of the same, Quran announces punishment for those who do not follow the righteous path, "And their taking usury though indeed they were forbidden it and their devouring the property of people falsely, and We have prepared for the unbelievers from among them a painful chastisement." [101].

Islamic financial system strongly condemns the monopolized control of market by handful of companies. There are companies who are that big that they appear in a position to dictate the markets but Islam encourages small and medium companies to come forward in a free trade and healthy competitive environment so that everyone can be benefitted in a society and distribution of wealth be justified in this way.

\section{End Note}

The captioned topic is very lengthy and comprehensive but we have tried to fo- 
cus our discussion only on those aspects of Islam as a religion that were presented by Marx. There are other valid dimensions of religion that can be taken into account and we invite other researchers to come forward and review Marx's religious ideas in the perspective of these multi-faceted dimensions. Marx used the word religion in a much generalized manner and as we have expounded earlier that he referred only to Christianity and Jewism. It must be kept in mind that these three core religions are in continuation as G-d sent Moses ${ }^{\text {as }}$ then Jesu$\mathrm{s}^{\text {as }}$ and finally Holy Prophet Muhammad ${ }^{\text {pbuh }}$. Since that there has been no prophet after Holy Prophet ${ }^{\mathrm{pbuh}}$ and Islam has been given as a final code of life that is why it was coded, drafted, maintained and documented in such a way that it covers every aspect of a human's life. If a religion is not being practiced in its true sense then we cannot reject or contradict its teachings or foundations. We can only frame logical or rational argument against a religion if it carries those shortcomings that leave it less beneficial for humanity but it is not the case with Islam.

The sense of reaction and intensity found in Marx writings against religion is purely personal and carries no rationality on the basis of which he nullifies any and every religion; that is why, it is requested that we better re-visit Marx's religious dogmas in the very bright perspective of pure religious foundations, especially Islamic one, in order to see, if religion is an opium for the people or not.

\section{References}

[1] Borris, I.N. and Helfen, O.M. (1976) Karl Marx: Man and Fighter. Penguin, New York.

[2] Boroson, W. (2010) Was Karl Marx Jewish? http://jewishstandard.timesofisrael.com/was-karl-marx-jewish/

[3] Macionis, G. (2010) Sociology. 7th Canadian Edition, Pearson Canada Inc., Ontario, Canada.

[4] DeRosso, D. (2015) The Structural-Functional Theoretical Approach. https://www.wisc-online.com/learn/social-science/sociology/i2s3404/the-structuralfunctional-theoretical-approac

[5] Marx, K. (1843) Introduction to a Contribution to the Critique of Hegel's Philosophy of Right. Translated by Mckinnon, A.M. (1976), Collected Works, Vol. 3, New York.

[6] Raines, J. (2002) Introduction. In: Marx on Religion, Temple University Press, Philadelphia.

[7] Cline, A. (2017) Religion as Opium of the People. https://www.thoughtco.com/religion-as-opium-of-the-people-250555

[8] Boer, R. (2009) The Full Story: On Marxism and Religion. International Socialism, No. 123. http://isj.org.uk/the-full-story-on-marxism-and-religion/

[9] Blunden, A. (2009) A Contribution to the Critique of Hegel's Philosophy of Right. https://www.marxists.org/archive/marx/works/1843/

[10] Craig, C.J. (2002) Classical Sociological Theory. Wiley-Blackwell, New York.

[11] Durkheim, É. (2007) The Rules of Sociological Method (1895). In: Appelrouth, S. and Edles, L.D., Eds., Classical and Contemporary Sociological Theory: Text and Readings, Pine Forge Press, Thousand Oaks, CA. 
[12] (2016) The Holy Bible. English Standard Version (Galatians 5:19-21). https://www.biblegateway.com

[13] (2016) The Holy Bible. English Standard Version (Corinthians 6:9). https://www.biblegateway.com

[14] Ali, A.Y., Trans. (2011) English Translation of Holy Quran (49:13). Tahrike Tarsile Qur'an Incorporated, New Delhi.

[15] Ali, A.Y., Trans. (2011) English Translation of Holy Quran (16:90-91). Tahrike Tarsile Qura'n Incorporated, New Delhi.

[16] Heelas, P. (2009) Spiritualities of Life: New Age Romanticism and Consumptive Capitalism. John Wiley \& Sons, Hoboken, NJ.

[17] James, W. and Marty, M. (1982) The Varieties of Religious Experience: A Study in Human Nature. Penguin Books, New York.

[18] Richardson, R. and James, W. (2010) The Heart of William James. Belknap Press of Harvard University Press, Cambridge, MA.

[19] Holt, J. (2015) The Social Thought of Karl Marx. Sage, New York.

[20] Seligman, E. (1901) The Economic Interpretation of History. Political Science Quarterly, 16, 612-640. https://doi.org/10.2307/2140420

[21] Marx, K. (1977) A Contribution to the Critique of Political Economy. Progress Publishers, Moscow.

[22] (2016) The Holy Bible. English Standard Version (Luke 12: 24-27). https://www.biblegateway.com

[23] Jacobs, L. (1997) Jewish Mystical Testimonies. Schocken, New York.

[24] Ali, A.Y., Trans. (2011) English Translation of Holy Quran (3:17). Tahrike Tarsile Qur'an Incorporated, New Delhi.

[25] Ali, A.Y., Trans. (2011) English Translation of Holy Quran (9:112). Tahrike Tarsile Qura'n Incorporated, New Delhi.

[26] Ali, A.Y., Trans. (2011) English Translation of Holy Quran (17: 79-80). Tehrike Tarsile Qura'n Incorporated, New Delhi.

[27] Ali, A.Y., Trans. (2011) English Translation of Holy Quran (2: 63-66). Tehrike Tarsile Qura'n Incorporated, New Delhi.

[28] Ali, A.Y., Trans. (2011) English Translation of Holy Quran (26:217-220). Tehrike Tarsile Qura'n Incorporated, New Delhi.

[29] Ali, A.Y., Trans. (2011) English Translation of Holy Quran (39:9). Tehnrike Tarsile Qura'n Incorporated, New Delhi.

[30] Ali, A.Y., Trans. (2011) English Translation of Holy Quran (50:39-40). Tehrike Tarsile Qura'n Incorporated, New Delhi.

[31] Limnatis, G.N. (2008) German Idealism and the Problem of Knowledge: Kant, Fichte, Schelling, and Hegel. Springer, Netherlands.

[32] Copleston, F.C. (2003) A History of Philosophy: Volume 7: 18th and 19th Century German Philosophy. Continuum International Publishing Group, New York.

[33] Alex, C. (1983) The Revolutionary Ideas of Karl Marx. Bookmarks, Bloomsbury, London.

[34] Wolff, R. and Resnick, S. (1987) Economics: Marxian versus Neoclassical. Johns Hopkins University Press, Baltimore.

[35] Thomas, A. (2005) Constructing "Godless Communism": Religion, Politics, and Popular Culture, 1954-1960. Americana: The Journal of American Popular Culture 
(1900-Present), 4, 1.

http://www.americanpopularculture.com/journal/articles/spring_2005/aiello.htm

[36] (2016) The Holy Bible. English Standard Version (Matthew 7: 21-13).

https://www.biblegateway.com

[37] (2016) The Holy Bible. English Standard Version (Galatians 5:19-26). https://www.biblegateway.com

[38] Rosenberg, R.A.J. (1993) The Complete Tanach with Rashi's Commentary (5636). https://www.chabad.org/library/bible_cdo/aid/63255/jewish/The-Bible-with-Rashi. htm

[39] Rosenberg, R.A.J. (1993) The Complete Tanach with Rashi's Commentary (Deuteronomy 5: 16-21).

https://www.chabad.org/library/bible_cdo/aid/63255/jewish/The-Bible-with-Rashi. $\underline{\mathrm{htm}}$

[40] Ali, A.Y., Trans. (2011) English Translation of Holy Quran (2:17). Tahrike Tarsile Qur'an Incorporated, New Delhi.

[41] Ali, A.Y., Trans. (2011) English Translation of Holy Quran (6:160). Tahrike Tarsile Qura'n Incorporated, New Delhi.

[42] Stephen, P. (1991) Theories of the Mind. Penguin Books, London.

[43] Novack, G. (1979) The Origins of Materialism. Pathfinder Press, New York.

[44] Moser, P.K. and Trout, J.D. (1995) Contemporary Materialism: A Reader. Psychology Press, Hove. https://doi.org/10.4324/9780203427262

[45] Uchegbue, C.O. (2011) A Critical Evaluation of Marx's Theory of Religion. American Journal of Social Issues \& Humanities, 1, 50-81.

[46] Walter, B. (1985) Greek Religion. Harvard University Press, Cambridge, MA.

[47] Europe (2018) Encyclopedia Britannica. https://www.britannica.com/place/Europe

[48] Bhaduri, A. (1969) On the Significance of Recent Controversies on Capital Theory: A Marxian View. Economic Journal, 79, 532-539.

[49] Ali, A.Y., Trans. (2011) English Translation of Holy Quran (22:41). Tahrike Tarsile Qur'an Incorporated, New Delhi.

[50] Ali, A.Y., Trans. (2011) English Translation of Holy Quran (5:8). Tahrike Tarsile Qura'n Incorporated, New Delhi.

[51] Darwish, A.A. (2015) Principles of Good Governance in Islam. https://www.linkedin.com/pulse/principles-good-governance-islam-ali-ahmad-dar wish

[52] Ali, A.Y., Trans. (2011) English Translation of Holy Quran (42:39). Tahrike Tarsile Qur'an Incorporated, New Delhi.

[53] Shafaat, A. (1989) On the Political System of the Islamic State. American Trust Publications, Oak Brook, IL.

[54] Ali, A.Y., Trans. (2011) English Translation of Holy Quran (3:159). Tahrike Tarsile Qur'an Incorporated, New Delhi.

[55] Bukhari, A.M. (1 April 2017) Hadith \# 893. https://www.sahih-bukhari.com

[56] Hoosen, A.K. (1990) Imam Tirmidhi's Contribution towards Hadith (Hadith \# 2029). 1st Edition, Newcastle, South Africa.

[57] Ali, A.Y., Trans. (2011) English Translation of Holy Quran (33:36). Tahrike Tarsile Qura'n Incorporated, New Delhi. 
[58] Ali, A.Y., Trans. (2011) English Translation of Holy Quran (24:63). Tahrike Tarsile Qura'n Incorporated, New Delhi.

[59] Ernest, M. (1970) Marxist Economic Theory. Vol. 1 and Vol. 2, Monthly Review Press, New York.

[60] Mahmasani, S. (2000) The Philosophy of Jurisprudence in Islam. Translated by Farhat J. Zaideh, The Open Press, Kuala Lumpur.

[61] Karim, S.A. (2010) The Islamic Moral Economy: A Study of Islamic Money and Financial Instruments. Brown Walker Press, Boca Raton, FL.

[62] Ishaque, K.M. (1983) Islamic Approach to Economic Development. In: Esposito, J.L., Ed., Voices of Resurgent Islam, 268-276.

[63] Khan, M.A. (1994) An Introduction to Islamic Economics. International Institute of Islamic Thought, and Institute of Policy Studies, Islamabad.

[64] Ali, A.Y., Trans. (2011) English Translation of Holy Quran (9:35). Tahrike Tarsile Qur'an Incorporated, New Delhi.

[65] Krichene, N. (2012) Islamic Capital Markets: Theory and Practice. John Wiley \& Sons, San Francisco, CA. https://doi.org/10.1002/9781119199106

[66] Askari, H., Iqbal, Z., Krichenne, N. and Mirakhor, A. (2011) The Stability of Islamic Finance: Creating a Resilient Financial Environment for a Secure Future. John Wiley \& Sons, San Francisco, CA.

[67] Davari, M.T. (2009) The Political Thought of Ayatollah Murtaza Mutahhari: An Iranian Theoretician of the Islamic State. Routledge, Abingdon, UK.

[68] Zaman, A. (2015) Re-Defining Islamic Economics. In: Egri, T. and Kizilkaya, N., Eds., Islamic Economics: Basic Concepts, New Thinking and Future Directions, Cambridge Scholars Publishing, UK.

[69] Weiss, D. (1995) Ibn Khaldun on Economic Transformation. International Journal of Middle East Studies, 27, 29-37. https://doi.org/10.1017/S0020743800061560

[70] Mallat, C. (1993) The Renewal of Islamic Law: Muhammad Baqer as-Sadr, Najaf, and the Shi'i International. Cambridge University Press, Cambridge. https://doi.org/10.1017/CBO9780511583889

[71] Ali, A.Y., Trans. (2011) English Translation of Holy Quran (24: 33). Tahrike Tarsile Qur'an Incorporated, New Delhi.

[72] Ali, A.Y., Trans. (2011) English Translation of Holy Quran (7: 7). Tahrike Tarsile Qura'n Incorporated, New Delhi.

[73] Ali, A.Y., Trans. (2011) English Translation of Holy Quran (10: 34). Tahrike Tarsile Qura'n Incorporated, New Delhi.

[74] Ali, A.Y., Trans. (2011) English Translation of Holy Quran (59:7) Tahrike tarsile Qura'n Incorporated, New Delhi.

[75] Zimbalist, S., Brown, A., Howard, J. and Stuart (1988) Comparing Economic Systems: A Political-Economic Approach. Harcourt College Pub.

[76] Denton, J.A. (1990) Society and the Official World: A Reintroduction to Sociology. General Hall, Dix Hills, New York.

[77] Jolly, R. (1976) The World Employment Conference: The Enthronement of Basic Needs. Development Policy Review, A9, 31-44. https://doi.org/10.1111/j.1467-7679.1976.tb00338.x

[78] Mustafa, I., et al. (1973) Al-Mu'jam al-Waseet Fi Tasreef al-Afaal, Vol.1. Al-Maktaba al-Islamiyah, Istanbul. 
[79] Al-Shaykh Abu Ishaq Ibrahim ibn Musa al-Shatibi al-Andalusi (1975) Al-Muwafaqat Fi Usul Al-Shari'ah, Vol. 2. Al Maktabah al-Tijiriyah al-Kubra, Cairo.

[80] Hisbullah, A. (1977) Usool-al-Tashreeh-al-Islami. Al-Quran-walUlum, Karachi.

[81] Ali, A.Y., Trans. (2011) English Translation of Holy Quran (51:19). Tahrike Tarsile Qur'an Incorporated, New Delhi.

[82] Maududi, S.A. (1984) Tafheem-ul-Qur'an, Vol. 5. Idarah Tarjman-ul Quran, Lahore.

[83] Imam Abu Eisa (2014) Al-Jami’ al-Tirmidhi, Hadith \# 2320. http://daruliftaa.com/node/7130

[84] Ghazali, I. (2000) Ihya' 'Ulum al-Deen, Vol. 3. Dar al-Wafa' lilTiba ahwa-al-Nashrwa-al-Tawzi, Beirut.

[85] Ghazali, I. (2000) Ihya' Ulium al-Deen, Vol. 4. Dar al-Wafa' lilTiba'ahwa-al-Nashrwa-al-Tawzi.

[86] Abu'l-Fadl al-Damashqi (1977) al-Isharathwal Mahasinaltijarat. alKulliyat al-Azhria, Cairo.

[87] BurhanUddin Abu Al-Hasan Ali Ibn Abu BakrIbn Abdul Jaleel al-Rushdani al-Marghinani (1997) Hedaya. Idarat-ul-Quran-walUloom-al-Islamia, Karachi.

[88] Shamsi, N. (2003) Human Rights and Islam. Reference Press, New Delhi.

[89] Shahab al-Din, Abu al-'Abbas, Ahmad bin Hussain bin Hasan bin 'Ali bin Yusuf bin 'Ali bin Arsalan, al-Ramli, al-Shafi'i (1967) Nihayat almuhtajilásharh al-Minhaj fi al-fiqh'alámadhhab al-imam al-Shaf'i. Vol. 6. Matbaaat al-Babi-al-Halli.

[90] Al Sajistani, A.D. (1986) Sunan Abi Daud, Kitab-ul Kharaj wal Amarah wal Fai, "Bab Arzaak ul Maal", Hadith \# 2571. Majlis-e-Ilmi Dar-ul-Daa’wa, New Delhi, India.

[91] Ali, A.Y., Trans. (2011) English Translation of Holy Quran (11:85). Tahrike Tarsile Qur'an Incorporated, New Delhi.

[92] Eisa, I.A. (2014) Al-Jami’ al-Tirmidhi, Hadith \# 3741. http://daruliftaa.com/node/7130

[93] Bukhari, A.M. (2017) Hadith \# 661. https://www.sahih-bukhari.com

[94] Bukhari, A.M. (2017) Hadith \# 7150. https://www.sahih-bukhari.com

[95] Eisa, I.A. (2014) Al-Jami' al-Tirmidhi, Hadith \# 2174. http://daruliftaa.com/node/7130

[96] Addas, W. (2008) Methodology of Economics: Secular vs Islamic. International Islamic University Malaysia Press, Malaysia.

[97] Khan, F.M. (2016) Islamic Financial System: A Brief Introduction. https://islamicbanker.com/education/islamic-financial-system-brief-introduction

[98] Mubarak, A. (2007) The Fundamentals of Islamic Finance. Al-Azhar Printing Press, Cairo.

[99] Ali, A.Y., Trans. (2011) English Translation of Holy Quran (2:276). Tahrike Tarsile Qur'an Incorporated, New Delhi.

[100] Ali, A.Y., Trans. (2011) English Translation of Holy Quran (2: 278). Tahrike Tarsile Qura'n Incorporated, New Delhi.

[101] Ali, A.Y., Trans. (2011) English Translation of Holy Quran (4:161). Tahrike Taesile Qura'n Incorporated, New Delhi. 